\title{
German state challenges faculty reappointments
}

\section{Races grease the wheels of science}

Tokyo. Scientists coming to Japan for conferences on neural networks and biomaterials are sometimes surprised to discover small print in their conference programme explaining that the event is supported in part from the profits of bicycle races.

Conferences are just one of many activities related to the development of future technology undertaken by Keirin, an association overseen by the Ministry of International Trade and Industry (MITI) that distributes some of the huge profits arising from betting on bicycle races.

Bicycle races are held almost every day in Japan at 50 locations, and bets can placed at the race tracks or by telephone by registered users anywhere in the country. About $¥ 2,000$ billion (US $\$ 18$ billion) each year is spent on ticket sales and bets, and the total continues to rise.

When Keirin was established in 1948 its role was to support the bicycle industry, but in the late 1950s it began to support a variety of machine industries. Now a significant part of Keirin's annual budget of about $¥ 35$ billion (US $\$ 315$ million) for machine industry grants supports the development of future technologies.

For example, Keirin helps to support the Research and Development Organization for Future Electron Devices, an association of 25 companies set up by MITI in 1981. It also gives about $¥ 2$ billion a year to the Japan Industrial Policy Research Institute, a non-profit organization that disperses small grants and contracts.
Munich. A German court has given Armin Ermisch his job back at Leipzig University, but the cell biologist sits at home because state government officials refuse to accept the court directives.

Hans Joachim Meyer, research minister for the east German Länder of Saxony, is challenging court orders to reinstate 13 professors sacked last year for allegedly collaborating with Stasi, the secret police for the former DDR. The order will be challenged as a matter of principle, Meyer says,

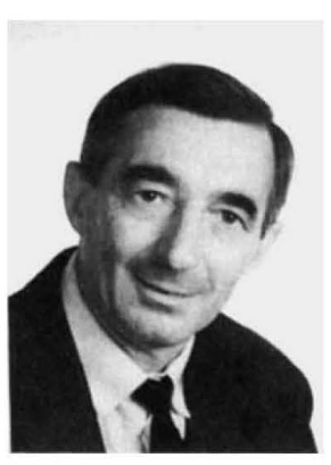

Armin Ermisch although no new evidence exists.

The controversial sackings last year were part of a package of dismissals in the restructuring of universities in the six new Länder following the reunification of Germany (see Nature 359, 762; 1992). In Saxony, more than 5,000 academic staff were sacked from the chronically overstaffed universities. Most were simply declared surplus to the new requirements, but 989 were sacked on the recommendation of the Personalkommissionen, groups of locally selected people set up to assess the 'personal integrity' of academics.

The democracy of the decisions, final responsibility for which rests with Saxony's

\section{SmithKline backs sequencing company}

Washington. Human Genome Sciences Inc. (HGS) of Rockville, Maryland - formed last year to commercialize products from the large-scale gene sequencing programme at the nearby Institute for Genomic Research (see Nature 358, 95; 1992) - has formed a strategic alliance with the Anglo-American pharmaceutical company SmithKline Beecham (SKB).

The agreement, believed to be worth upwards of $\$ 100$ million, gives SKB the exclusive worldwide rights to diagnostic, therapeutic and vaccine products and services developed from the gene sequencing data generated through the collaboration. In return, HGS will receive royalty payments on the sales of any product developed in the human and animal health sectors as well as an equity investment by the drug company. HGS will, however, retain the rights to use its gene sequencing data in gene therapy and for the development of therapeutic agents based on antisense technology.

Although the collaboration is unlikely to produce products in the near-term, Stewart Adkins, an analyst with Shearson Lehman, believes SKB sees it as a "long-term opportunity... worth funding because there are so many things that could come out of it".

One week before the agreement was reached, HGS announced the hiring of William A. Haseltine as chief executive officer and chairman of the board. Haseltine, who has taken a two-year leave of absence from the Dana-Farber Cancer Institute in Boston, says that HGS had been in discussions with a number of other pharmaceutical companies and that he is "delighted that we [HGS] have formed an alliance" with SKB.

Diane Gershon research minister, was widely challenged Many of the victims felt that the Personalkommissionen were influenced by personal motives, and 303 took their cases to court.

A tally on the cases, most of which were heard earlier this year, is difficult because no central records are maintained. However, it is believed that most reached a settlement, without any conclusion about whether the allegations were true.

However in 13 cases the courts clearly ruled in favour of the plaintiffs, finding no evidence to suggest that the accused had in any way abused their posts in the Communist Party to the detriment of their colleagues or their students. The government was ordered to reinstate these professors.

Meyer says he will continue to accept the opinions of the Personalkommissionen against those of the court as long as he has the legal right of challenge. He denies that he is being inflexible, saying instead that he changed his mind about many dismissals when more evidence came to light (the Personalkommissionen had originally recommended dismissal of 1,651 staff on the grounds of 'personal integrity').

"Since 1968, academic institutions have become instruments of party rule, and this has to change", he says. "I'm not acting as a judge or handing out sentences. I'm simply acting as the cabinet minister responsible for [these changes]."

Ermisch lost his university post at the end of last year but was put back on the payroll in February after a favourable ruling by the labour court in Dresden. But the university, on Meyer's recommendation, asked biology director Karl Drössler to reach "a sensible compromise" with Ermisch (as with all the reinstated professors) in the run up to Meyer's appeals to the Länd labour court. "We agreed that professor Ermisch should work mostly at home while the trial was still going on", says Drössler. But Ermisch finds this solution unsatisfactory because he is able to work only on material brought to him by his students. Wolf-Dietrich Arnold of Leipzig University's orthopaedic clinic is in the same position.

Friedel Schnur, a lawyer representing three of the 13 professors, says that Meyer is just being stubborn. "The court ruled in our favour and Meyer has nothing new to say", he says. "We don't expect him to win his appeal, but if he does, we will counterappeal."

If the Länd labour court decides that the Dresden court had the right to overturn the decision of Meyer and his Personalkommission, the minister can appeal to the federal court. The Länd court will decide whether or not to allow the appeal.

Alison Abbott 